Volume 3

Issue 4 -- Cardiovascular Aging

Article 6

$11-11-2016$

\title{
Atrial Fibrillation and Stroke in Elderly Patients
}

Geetanjali Dang

Imaan Jahangir

Jasbir Sra

A. Jamil Tajik

Arshad Jahangir

Follow this and additional works at: https://aah.org/jpcrr

Part of the Cardiology Commons, Cardiovascular Diseases Commons, and the Therapeutics

Commons

\section{Recommended Citation}

Dang G, Jahangir I, Sra J, Tajik AJ, Jahangir A. Atrial fibrillation and stroke in elderly patients. J Patient Cent Res Rev. 2016;3:217-29. doi: 10.17294/2330-0698.1409

Published quarterly by Midwest-based health system Advocate Aurora Health and indexed in PubMed Central, the Journal of Patient-Centered Research and Reviews (JPCRR) is an open access, peer-reviewed medical journal focused on disseminating scholarly works devoted to improving patient-centered care practices, health outcomes, and the patient experience. 


\title{
Atrial Fibrillation and Stroke in Elderly Patients
}

\author{
Geetanjali Dang, MD, ${ }^{1,2}$ Imaan Jahangir, ${ }^{3}$ Jasbir Sra, MD, ${ }^{4}$ A. Jamil Tajik, MD, ${ }^{2,4}$ Arshad Jahangir, MD ${ }^{2,4}$ \\ ${ }^{1}$ Medical College of Wisconsin, Milwaukee, WI \\ ${ }^{2}$ Sheikh Khalifa bin Hamad Al Thani Center for Integrative Research on Cardiovascular Aging, Aurora Research \\ Institute, Milwaukee, WI \\ ${ }^{3}$ Aurora Health Care, Milwaukee, WI \\ ${ }^{4}$ Aurora Cardiovascular Services, Aurora Health Care, Milwaukee, WI
}

\begin{abstract}
The increasing prevalence of stroke, with an estimated annual cost of $\$ 71.5$ billion, has made it a major health problem that increases disability and death, particularly in patients with atrial fibrillation. Although advanced age and atrial fibrillation are recognized as strong risk factors for stroke, the basis for this susceptibility are not well defined. Aging or associated diseases are accompanied by changes in rheostatic, humoral, metabolic and hemodynamic factors that may contribute more to stroke predisposition than rhythm abnormality alone. Several thromboembolism-predisposing clinical characteristics and serum biomarkers with prognostic significance have been identified in patients with atrial fibrillation. Although anticoagulation decreases the risk of thromboembolism, management in the elderly remains complex due to major concerns about bleeding. New anticoagulants and nonpharmacologic strategies are helpful to reduce the risk of bleeding, particularly in older-elderly patients. Herein, we review the pathogenesis and management of select issues of thromboembolism in the elderly with atrial fibrillation. (J Patient Cent Res Rev. 2016;3:217-229.)
\end{abstract}

Keywords aging; warfarin; atrial fibrillation; antiplatelet agents; stroke; novel anticoagulant; atrial appendage occlusion

Atrial fibrillation (AF) is the most common cardiac arrhythmia, primarily affecting the senescent heart. Its increase with age is apparent in the greater prevalence of $\mathrm{AF}$ in octogenarians than in patients younger than 55 years old ( $9 \%-10 \%$ vs $0.1 \%$, respectively, a 100 fold increase). ${ }^{1-3}$ Thromboembolic stroke is one of the most feared complications of atrial fibrillation. In 2013, there were 6.5 million stroke deaths worldwide, making stroke the second-leading global cause of death behind ischemic heart disease. ${ }^{4}$ Each year, about 795,000 people in the United States experience a new or recurrent stroke. Approximately 610,000 of these are first episodes; 185,000 are recurrent ones. On average, every 40 seconds, someone in the United States has a stroke. ${ }^{2}$ Projections show that by 2030 an additional 3.4 million adults will have had a stroke, a $20.5 \%$ increase in prevalence from 2012. ${ }^{2}$

Correspondence: Arshad Jahangir, MD,

2801 W. Kinnickinnic River Parkway, \#235,

Milwaukee, WI 53215, T: 414-649-3909,

Email: publishing44@aurora.org
$\mathrm{AF}$ is a powerful risk factor for stroke, independently increasing risk about fivefold in those with nonvalvular $\mathrm{AF}$ and more than 20-fold in those with mitral stenosis, with a very high risk of recurrent stroke, disability and mortality. ${ }^{5}$ The percentage of strokes attributable to AF increases steeply from $1.5 \%$ at $50-59$ years of age to $23.5 \%$ at 80 89 years. The average stroke rate was reported at $4.1 \%$ per year among the primary prevention studies for $\mathrm{AF}$ and $13 \%$ per year among those with prior stroke or transient ischemic attack (TIA). ${ }^{1}$ Important risk factors for stroke in the setting of AF include advancing age, hypertension, heart failure, diabetes mellitus, previous stroke or TIA, vascular disease and female sex. Additional circulating biomarkers of fibrosis or cardiac stress, including high levels of troponin and brain natriuretic peptide, increase the risk of stroke in the setting of AF independent of those well-established clinical characteristics. ${ }^{6,7}$

Women accounted for $58 \%$ of U.S. stroke deaths in 2013. ${ }^{2}$ More women than men die of stroke each year because of the larger number of elderly women. In the setting of AF, women have a significantly higher risk of stroke than men. ${ }^{2,8}$ The prevalence of stroke survivors 
is projected to increase along with the aging of the population, especially among elderly women. Patients older than 85 years of age make up $17 \%$ of all stroke patients. $^{2}$ Very elderly patients (age $>85$ years) have a higher risk-adjusted mortality and risk of disability, have longer hospitalizations, receive less evidencedbased care and are less likely to be discharged to their original place of residence. ${ }^{9}$

According to analyses from the U.S. Nationwide Inpatient Sample, over the past decade, in-hospital mortality rates after stroke have declined for every age except men older than 84 years. Over the next 40 years (2010-2050), the number of incident strokes is expected to more than double, with the majority of the increase among patients aged $\geq 75$ years as well as in minority groups. Between 2012 and 2030, total direct medical stroke-related costs are projected to triple, from $\$ 71.6$ billion to $\$ 184.1$ billion, with the majority of the projected increase in costs arising from those 65-79 years of age. ${ }^{2}$ With a problem of this magnitude, the health and economic implications of thromboembolism associated with $\mathrm{AF}$ are farreaching. ${ }^{2,10}$ There is a growing need to better understand the mechanisms that underlie aging-associated changes in the cardiovascular system that predispose people to $\mathrm{AF}$ and thromboembolism. ${ }^{6,11}$ Active research in these areas has focused on identification of novel therapeutic targets for prevention to reduce the incidence of $\mathrm{AF}$ and its associated thromboembolic risk. ${ }^{12,13}$ This overview highlights the pathogenesis and management of stroke and thromboembolism associated with $\mathrm{AF}$ in elderly patients.

\section{Pathogenesis of Thromboembolism in Patients With Atrial Fibrillation}

Ischemic stroke in patients with AF usually is attributed to embolism from thrombus in the left atrium or the left atrial appendage (LAA), although as many as $25 \%$ of strokes may be due to intrinsic cerebrovascular disease. ${ }^{14}$ Hypercoagulability, left atrium or LAA stasis, and endothelial injury reinforce the traditional Virchow concept implicated in thrombogenesis. ${ }^{15}$ Therefore, thrombogenic states, such as heart failure, diabetes, aging or history of stroke, as well as conditions that can lead to atrial stasis (poorly contracting dilated left atrium, ventricle with spontaneous echocardiographic contrast, LAA sludge, mitral stenosis) or endothelial dysfunction/ injury (hypertension, vascular disease) increase the risk of stroke and thromboembolism in patients with AF. ${ }^{16-19}$
Abnormalities in blood flow and vessels can be related to the presence of structural heart disease or extrinsic interventions such as cardioversion that can lead to atrial stunning, promoting a prothrombotic state mostly within the first 10 days after the cardioversion. ${ }^{17,18,20-24}$ Valvular heart disease, especially mitral stenosis, increases the risk of stroke in AF 17-fold. ${ }^{12}$

Episodes of AF themselves promote a procoagulant state with an increase in markers of platelet activation (betathromboglobulin and platelet factor 4), thrombogenesis (elevated fibrinogen, prothrombin fragment $\mathrm{F} 1+2$, thrombin-antithrombin complexes, D-dimer levels) and endothelial dysfunction or injury (elevated von Willebrand factor, soluble E-selectin levels), independent of the presence of structural heart disease, increasing the likelihood of thromboembolism. ${ }^{6,11,16,22,23,25-30}$ Evidence also points to endocardial or endothelial dysfunction with decreased anticoagulant mechanisms - such as expression of nitric oxide synthase, tissue factor pathway inhibitor and thrombomodulin — and an increase in procoagulant factors such as plasminogen activator inhibitor- $1^{22,23,31}$ as a possible mechanism for thromboembolism in the setting of AF. Inflammation with elevated C-reactive protein and interleukin- 6 is associated with a prothrombotic state and an increase in reactive oxygen species production that promotes platelet hyperactivity and additional susceptibility to thrombosis, contributing to an overall hypercoagulable state in AF. This is particularly evident in the elderly with aging-associated diseases, including diabetes, heart failure and hypertension, which further increase thrombogenicity. ${ }^{6,28,32-34}$ In addition, atrial stretch associated with AF and myocardial dysfunction leads to downregulation of thrombomodulin, which renders a defective anticoagulant defense in AF patients and, thus, predisposes these patients to stroke. ${ }^{35}$

\section{Management of Thromboembolism in Elderly Patients}

The three main areas in the management of patients with $\mathrm{AF}$ are maintenance of sinus rhythm, control of ventricular rate response during $\mathrm{AF}$, and prevention of complications like stroke, peripheral thromboembolism, heart failure and early mortality. ${ }^{1,36}$ Although rhythm control has been thought to be better than rate control, the landmark AFFIRM (Atrial Fibrillation Follow-up Investigation of Rhythm Management) trial, ${ }^{37}$ the RACE (Rate Control vs Electrical Cardioversion [for persistent atrial 
fibrillation]) trial, ${ }^{38}$ and the AF-CHF (Atrial Fibrillation and Congestive Heart Failure $)^{39}$ trial demonstrated that AF patients who had a high risk of thromboembolism did no better when treated with a strategy of pharmacologic rhythm control than did AF patients treated with rate control in regard to reducing overall or cardiovascular mortality, hospitalization or risk of stroke.

Regardless of approach (rhythm vs rate control), these findings indicate that maintenance of a therapeutic level of anticoagulation is essential to reduce the risk of thromboembolism in AF patients at high risk of stroke. ${ }^{40}$ In addition, the type of AF (paroxysmal, persistent or permanent) or the absence of AF symptoms is not predictive of thromboembolism. ${ }^{1}$ More than one-third of patients with a history of AF treated with rhythm control alone may have recurrent paroxysmal AF that can be completely asymptomatic while still increasing the risk of thromboembolism. ${ }^{41}$ Recent data in patients with implantable loop recorder or cardiac devices indicate that even $\mathrm{AF}$ episodes lasting for 6 minutes can increase the risk of thromboembolism, ${ }^{42}$ and prolonged monitoring of the rhythm in those with cryptogenic stroke may reveal asymptomatic AF in up to $30 \%$ of the patients. ${ }^{43}$ Therefore, prophylactic intervention to reduce stroke risk should be considered in all $\mathrm{AF}$ patients at high risk for stroke.

\section{Risk Assessment for Stroke in AF Patients}

The $\mathrm{CHADS}_{2}, \mathrm{CHA}_{2} \mathrm{DS}_{2}$-VASc and HAS-BLED scoring systems (Table 1) are widely used to calculate the risk of thromboembolism and bleeding, respectively, in patients with nonvalvular $\mathrm{AF}^{5,25,44}$ The $\mathrm{CHADS}_{2}$ risk assessment system, developed after analysis of ischemic

Table 1. Comparison of $\mathrm{CHADS}_{2}, \mathrm{CHA}_{2} \mathrm{DS}_{2}$-VASc, and HAS-BLED Scores

\begin{tabular}{|c|c|c|c|c|c|}
\hline \multicolumn{2}{|c|}{ CHADS $_{2}$ score $^{a}$} & \multicolumn{2}{|c|}{ HAS-BLED score ${ }^{b}$} & \multicolumn{2}{|c|}{$\mathrm{CHA}_{2} \mathrm{DS}_{2}$-VASc score ${ }^{\mathrm{a}}$} \\
\hline Factor & Points & Factor & Points & Factor & Points \\
\hline $\mathrm{CHF}$ & 1 & Hypertension & 1 & $\overline{\text { Female }}$ & 1 \\
\hline Hypertension & 1 & Age $>65$ years & 1 & Age $65-74$ years & 1 \\
\hline Age $>75$ years & 1 & Stroke & 1 & Age $>75$ years & 2 \\
\hline Diabetes & 1 & Bleeding history & 1 & $\mathrm{CHF}$ & 1 \\
\hline \multirow[t]{4}{*}{ Previous stroke } & 2 & Labile INRs & 1 & Hypertension & 1 \\
\hline & & Drugs or alcohol abuse & 1 each & Diabetes mellitus & 1 \\
\hline & & $\begin{array}{c}\text { Abnormal renal or liver } \\
\text { dysfunction }\end{array}$ & 1 each & Vascular disease & 1 \\
\hline & & & & $\begin{array}{l}\text { History of stroke, TIA, } \\
\text { thromboembolism }\end{array}$ & 2 \\
\hline Total score & $\begin{array}{l}\text { Risk of stroke } \\
\text { (\%/year) }\end{array}$ & Total score & 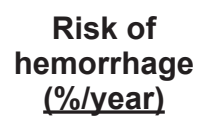 & Total score & $\begin{array}{c}\text { Risk of } \\
\text { stroke } \\
\text { (\%/year) }\end{array}$ \\
\hline 0 & 1.9 & 0 & 1.13 & 0 & 0.2 \\
\hline 1 & 2.8 & 1 & 1.02 & 1 & 0.6 \\
\hline 2 & 4.0 & 2 & 1.88 & 2 & 2.2 \\
\hline 3 & 5.9 & 3 & 3.74 & 3 & 3.2 \\
\hline 4 & 8.5 & 4 & 8.70 & 4 & 4.8 \\
\hline 5 & 12.5 & 5 & 12.50 & 5 & 7.2 \\
\hline \multirow[t]{4}{*}{6} & 18.2 & $6-9$ & $>12.5$ & 6 & 9.7 \\
\hline & & & & 7 & 11.2 \\
\hline & & & & 8 & 10.8 \\
\hline & & & & 9 & 12.2 \\
\hline
\end{tabular}

CHF, congestive heart failure; INR, international normalized ratio; TIA, transient ischemic attack.

${ }^{a}$ Data in left and right columns extracted from January et al. 2014 AHA/ACC/HRS guideline for the management of patients with atrial fibrillation: executive summary: a report of the American College of Cardiology/American Heart Association Task Force on Practice Guidelines and the Heart Rhythm Society. Circulation. 2014;130:2071-104.

${ }^{b}$ Center column was adapted from Pisters et al. A novel user-friendly score (HAS-BLED) to assess 1-year risk of major bleeding in patients with atrial fibrillation: the Euro Heart Survey. Chest. 2010;138:1093-100. 
stroke risk among patients with nonvalvular AF, assigns a score of 1 for congestive heart failure, hypertension, age $\geq 75$ years and diabetes mellitus, respectively, and a score of 2 for prior stroke/TIA or thromboembolism. ${ }^{45}$ There is an increase in stroke rate of approximately $2 \%$ for each 1-point increase in $\mathrm{CHADS}_{2}$ score, ranging from $1.9 \%$ with a score of 0 to $18.2 \%$ with a score of $6 .^{1,45}$

The $\mathrm{CHA}_{2} \mathrm{DS}_{2}$-VASc score assigns 1 point each to congestive heart failure, hypertension, age 65-74 years, diabetes mellitus, female sex and vascular disease and 2 points each to prior stroke/TIA or thromboembolism and age $>75$ years. It is considered the preferred tool to assess the embolic risk in patients with nonvalvular $\mathrm{AF}^{25,46} \mathrm{~A}$ $\mathrm{CHA}_{2} \mathrm{DS}_{2}$-VASc score of 2 or greater represents a high risk for stroke that requires initiation of anticoagulation.

An important safety concern with use of antithrombotic agents is the increased risk of major bleeding, requiring hospitalization, transfusion or surgery, or intracranial hemorrhage, which is associated with increased mortality and disability. The risk of intracranial hemorrhage is about $0.4 \%$ per year, which is lower than the risk of ischemic stroke in the majority of AF patients with $\mathrm{CHA}_{2} \mathrm{DS}_{2}$-VASc score $\geq 2$, if not anticoagulated. To quantify hemorrhage risk, several bleeding risk scores have been published, including HAS-BLED, which is based on the presence of hypertension, abnormal renal or liver function, history of stroke, bleeding predisposition, labile international normalized ratios (INRs), elderly age ( $>65$ years), or use of excess alcohol or drugs that promote bleeding. ${ }^{1,57-49} \mathrm{~A}$ score of 3 or higher indicates a "high risk" for bleeding that may require closer monitoring of anticoagulation and potential adverse effects. Chronic kidney disease, although not included in the $\mathrm{CHA}_{2} \mathrm{DS}_{2}$-VASc or $\mathrm{CHADS}_{2}$ risk prediction models, is a strong predictor of stroke risk as well as bleeding in patients with $\mathrm{AF},{ }^{18}$ therefore consideration for anticoagulation requires careful risk/benefit assessment.

\section{Pharmacological Strategies for Risk Reduction of Stroke in AF}

Anticoagulation with either warfarin (INR of 2.0 to 3.0) or one of the novel oral anticoagulants (NOACs) such as dabigatran, rivaroxaban, apixaban or edoxaban reduces the risk of ischemic stroke or thromboembolism by almost two-thirds in patients with nonvalvular AF and should be considered in high-risk patients with a $\mathrm{CHA}_{2} \mathrm{DS}_{2}$-VASc score of 2 or greater. ${ }^{1,25,27,33}$ Antiplatelet agents alone are not very effective in reducing the risk of stroke (19\% reduction [95\% confidence interval: $1 \%-35 \%]$ ), ${ }^{1,20,26}$ and most studies, with the exception of the Stroke Prevention in Atrial Fibrillation-1 trial, revealed no significant benefit in stroke reduction, especially in the older-elderly (age $>75$ years). ${ }^{1}$ Anticoagulants are associated with an increased risk of bleeding; therefore, the risk-to-benefit ratio needs to be carefully considered, especially in those at relatively low risk for thromboembolism, such as those with a $\mathrm{CHA}_{2} \mathrm{DS}_{2}$-VASc score less than 2. In patients with a $\mathrm{CHA}_{2} \mathrm{DS}_{2}$-VASc score of 1 with a reported risk of ischemic stroke varying from $<1 \%$ to $2.7 \%$ per year, no antithrombotic therapy or anticoagulation could be recommended depending on the presence of risk factors, with the highest risk in those 65-74 years old and with diabetes. ${ }^{18,21}$ For very low-risk patients $\left(\mathrm{CHA}_{2} \mathrm{DS}_{2}-\right.$ VASc score of 0 ), anticoagulant therapy usually is not recommended and clinical judgment is required to make an individualized decision. ${ }^{1}$

Despite the proven effectiveness of warfarin and NOACs in the prevention of stroke in high-risk patients, anticoagulants are underused for the prevention of stroke in elderly patients with $\mathrm{AF}^{30}$ In a recent study, common contraindications to the use of anticoagulation in patients $\geq 75$ years old were prior bleed $(32 \%)$, patient refusal (25\%), frequent falls or frailty $(25 \%)$, high bleeding risk $(20 \%)$, need for dual antiplatelet therapy $(9 \%)$, unable to adhere (5\%), prior intracranial hemorrhage $(5 \%)$, comorbid illness (5\%) and allergy $(2 \%){ }^{50}$ In elderly patients with multiple comorbidities and contraindications for anticoagulation, despite a $\mathrm{CHA}_{2} \mathrm{DS}_{2}$-VASc score necessitating anticoagulation (i.e. greater than 1), a goals-of-care discussion may be warranted.

\section{Role of Warfarin}

Evidence for the efficacy of warfarin, a vitamin K antagonist that affects clotting factors II, VII, IX and $\mathrm{X}$, in risk reduction for stroke in patients with $\mathrm{AF}$ at moderate to high risk for thromboembolism comes from randomized control trials conducted in the 1990s. These trials demonstrated a significant two-thirds reduction in the incidence of clinical stroke at an acceptable risk of bleeding compared to placebo or the antiplatelet agent aspirin. ${ }^{1,35}$ In addition, compared to no anticoagulant therapy, the use of warfarin reduces the severity of stroke and stroke mortality. ${ }^{19}$ The relative risk reduction with warfarin in stroke patients was greater in patients with a higher risk for stroke (rates of $>6 \%$ per year). 
In the general population, anticoagulation with warfarin reduced the risk of stroke from $>4.5 \%$ per year to about $1.5 \%$ per year. ${ }^{1}$ The bleeding risk $(1 \%-3 \%$ per person-year) is higher during the initiation phase, with concomitant illnesses affecting warfarin pharmacokinetics or use of medicines or supplements that affect hemostasis. ${ }^{35}$ The annual risk for intracranial hemorrhage with warfarin in AF patients in recent studies is low ( $0.2 \%$ to $0.4 \%$ per year) but is still up to two times higher than the risk for nonanticoagulated patients $(0.2 \%) .{ }^{17}$

Increasing age, prior stroke, hypertension and an INR $>3$ are the most important predictors of major bleeding. ${ }^{10}$ For high-risk patients younger than 75 years old, a prothrombin time with an INR range of 2 to 3 is safe and effective. ${ }^{29}$ For older patients ( $>75$ years), a lower target INR level (2 to 2.5) could be considered with close monitoring to reduce the likelihood of bleeding. Maintaining the therapeutic range of anticoagulation with warfarin is challenging due to its narrow therapeutic index, which is affected by various drug-drug and drug-food interactions as well as chronic comorbidities or acute illnesses that can reduce the time in the therapeutic range to $50 \%-65 \% .^{1,32}$ In addition, variability within the population in the expression of genes involved in warfarin metabolism (CYP2C9) and/or activation (VKORC) impacts warfarin dosing, especially at initiation, leading to a hypercoagulant state and risk for bleeding. ${ }^{51}$

The optimal approach to a patient with an elevated INR and warfarin-associated coagulopathy depends on the degree of INR elevation, ongoing bleeding and its location (e.g. intracranial), and the underlying thrombotic risk. ${ }^{52}$ In patients with serious or lifethreatening bleeding or those requiring an urgent surgery, rapid and full reversal of warfarin's effect is required with intravenous vitamin $\mathrm{K}$ or 4-factor prothrombin complex concentrate administration. ${ }^{48}$ Whereas, in those with no or minor bleeding, warfarin can be held without administration of a reversal agent, especially if the underlying thrombotic risk is particularly high.

\section{Novel Oral Anticoagulants: Alternatives to Warfarin}

To overcome some of the shortcomings of warfarin, several newer oral anticoagulants have been developed with a more predictable pharmacokinetic profile that avoids the need for routine monitoring of anticoagulation and has fewer drug-food interactions; these are expected to improve adherence to and persistence with an anticoagulant regimen by the elderly. ${ }^{1,12}$ However, renal function, bleeding and adherence still need to be monitored in these patients. NOACs are divided into those that directly inhibit thrombin or those with an inhibitory effect on clotting factor Xa. The United States has approved dabigatran (a direct thrombin inhibitor) and rivaroxaban, apixaban and edoxaban (factor Xa inhibitors) for risk reduction of stroke in patients with nonvalvular AF. These NOACs have been compared to warfarin in randomized controlled trials (Table $2^{53-58}$ ) and were found to be noninferior in risk reduction of stroke, with a statistically significant reduced risk of major, especially intracranial, bleeding in the elderly. The risk of gastrointestinal bleeding was higher with rivaroxaban than with warfarin. ${ }^{54}$ The initial evidence of increased risk of myocardial infarction in patients on rivaroxaban seen in the RE-LY trial was not confirmed in subsequent analysis of large observational studies. ${ }^{59}$ Patients with prosthetic heart valves, rheumatic valve disease, mitral stenosis or on protease inhibitors or other drugs with a strong modulating effect on P-glycoprotein or cytochrome $3 \mathrm{~A} 4$ are not candidates for NOACs, and warfarin remains the preferred anticoagulant. ${ }^{1,33}$

Predominant renal excretion remains a major limitation for the use of NOACs in the elderly population. Drugs like dabigatran and edoxaban cannot be used in patients with advanced renal impairment (e.g. stage 4 or 5 chronic kidney disease with creatinine clearance $<15 \mathrm{~mL} / \mathrm{min}$ ) and require dosage adjustment for those with moderate renal impairment (glomerular filtration rate $<60 \mathrm{~mL} / \mathrm{min} / 1.73$ $\mathrm{m}^{2}$ ). Further research is needed to determine the utility and safety of NOACs in elderly patients with chronic kidney disease and end-stage renal disease. Limited information is available about the efficacy and safety of these agents in the older-elderly, but apixaban and edoxaban appear to have a lower rate of bleeding compared to warfarin. ${ }^{33}$ No head-to-head comparison between the new anticoagulants in the elderly or those with moderate to severe renal impairment has been performed. Further research in defining the safety and efficacy of NOACs in patients with renal impairment is needed.

Pooled results $^{45}$ from the RE-LY (dabigatran), ${ }^{53}$ ARISTOTLE (apixaban) ${ }^{55}$ and ROCKET-AF (rivaroxaban) ${ }^{54}$ trials indicate that, compared to warfarin, NOACs in patients with nonvalvular AF are associated 
Table 2. Characteristics and Outcomes of Novel Anticoagulant Studies

\begin{tabular}{|c|c|c|c|c|}
\hline Variable & RE-LY (2009) ${ }^{53}$ & $\begin{array}{l}\text { ROCKET-AF } \\
(2011)^{54}\end{array}$ & $\begin{array}{l}\text { ARISTOTLE } \\
(2011)^{55}\end{array}$ & $\begin{array}{l}\text { ENGAGE AF-TIMI } 48 \\
(2013)^{56}\end{array}$ \\
\hline Design & Probe & Double-blind & Double-blind & Double-blind \\
\hline Trial size & $\mathrm{N}=18,113$ & $\mathrm{~N}=14,264$ & $\mathrm{~N}=18,201$ & $\mathrm{~N}=21,105$ \\
\hline Median follow-up & 2 years & 1.9 years & 1.8 years & 2.8 years \\
\hline Mean age & 71.5 years & 73 years & 70 years & 72 years \\
\hline Male sex & $63.5 \%$ & $59.3 \%$ & $64.5 \%$ & $61.9 \%$ \\
\hline Mean $\mathrm{CHADS}_{2}$ & 2.1 & 3.5 & 2.1 & 2.8 \\
\hline Mode of action & $\begin{array}{l}\text { Oral direct thrombin } \\
\text { inhibitor }\end{array}$ & $\begin{array}{l}\text { Oral direct factor } \mathrm{X}_{\mathrm{a}} \\
\text { inhibitor }\end{array}$ & $\begin{array}{l}\text { Oral direct factor } \mathrm{X}_{\mathrm{a}} \\
\text { inhibitor }\end{array}$ & $\begin{array}{l}\text { Oral direct factor } \mathrm{X}_{\mathrm{a}} \\
\text { inhibitor }\end{array}$ \\
\hline Half-life & $12-17$ hours & $5-13$ hours & 9-14 hours & 10-14 hours \\
\hline Inclusion criteria & $\begin{array}{l}\text { Nonvalvular AF + } \\
1 \text { risk factor }\end{array}$ & $\begin{array}{l}\text { Nonvalvular AF + } \\
2 \text { risk factors }\end{array}$ & $\begin{array}{l}\text { Nonvalvular AF + } \\
\text { CHADS }_{2} \geq 1\end{array}$ & $\begin{array}{l}\text { Nonvalvular AF + } \\
\text { CHADS }_{2} \geq 2\end{array}$ \\
\hline Intervention & $\begin{array}{l}\text { Dabigatran } 110 \mathrm{mg} \\
\text { b.i.d. } \\
\text { Dabigatran } 150 \mathrm{mg} \\
\text { b.i.d. }\end{array}$ & $\begin{array}{l}\text { Rivaroxaban } 20 \text { mg } \\
\text { daily }\end{array}$ & Apixaban 5 mg b.i.d. & $\begin{array}{l}\text { Edoxaban } 30 \mathrm{mg} \text { daily } \\
\text { Edoxaban } 60 \mathrm{mg} \text { daily }\end{array}$ \\
\hline Comparator & Open-label warfarin & Blinded warfarin & Blinded warfarin & Blinded warfarin \\
\hline Primary efficacy & $\begin{array}{l}\text { Stroke or systemic } \\
\text { embolism }\end{array}$ & $\begin{array}{l}\text { Stroke or systemic } \\
\text { embolism }\end{array}$ & $\begin{array}{l}\text { Stroke or systemic } \\
\text { embolism }\end{array}$ & $\begin{array}{l}\text { Stroke or systemic } \\
\text { embolism }\end{array}$ \\
\hline Primary safety & Major bleeding & $\begin{array}{l}\text { Major bleeding }+ \\
\text { clinically relevant } \\
\text { nonmajor bleeding } \\
\end{array}$ & Major bleeding & Major bleeding \\
\hline $\begin{array}{l}\text { Stroke/systemic } \\
\text { embolism }\end{array}$ & $\begin{array}{l}1.71 \% \text { warfarin } \\
1.54 \% \text { dabigatran } \\
110 \mathrm{mg} \\
1.11 \% \text { dabigatran }^{*} \\
150 \mathrm{mg}^{*} \\
\end{array}$ & $\begin{array}{l}2.4 \% \text { warfarin } \\
2.1 \% \text { rivaroxaban }\end{array}$ & $\begin{array}{l}1.6 \% \text { warfarin } \\
1.27 \% \text { apixaban* }\end{array}$ & $\begin{array}{l}1.5 \% \text { warfarin } \\
1.61 \% \text { edoxaban } 30 \mathrm{mg}^{*} \\
1.18 \% \text { edoxaban } 60 \mathrm{mg}^{*}\end{array}$ \\
\hline Major bleeding & $\begin{array}{l}3.57 \% \text { warfarin } \\
2.87 \% \text { dabigatran } \\
110 \mathrm{mg}^{*} \\
3.32 \% \text { dabigatran } \\
150 \mathrm{mg}\end{array}$ & $\begin{array}{l}3.4 \% \text { warfarin } \\
3.6 \% \text { rivaroxaban }\end{array}$ & $\begin{array}{l}3.09 \% \text { warfarin } \\
2.13 \% \text { apixaban* }\end{array}$ & $\begin{array}{l}3.43 \% \text { warfarin } \\
1.61 \% \text { edoxaban } 30 \mathrm{mg}^{*} \\
2.75 \% \text { edoxaban } 60 \mathrm{mg}^{*}\end{array}$ \\
\hline Intracranial hemorrhage & $\begin{array}{l}0.74 \% \text { warfarin } \\
0.23 \% \text { dabigatran } \\
110 \mathrm{mg}^{*} \\
0.3 \% \text { dabigatran }^{*} \\
150 \mathrm{mg}^{*} \\
\end{array}$ & $\begin{array}{l}0.7 \% \text { warfarin } \\
0.5 \% \text { rivaroxaban* }\end{array}$ & $\begin{array}{l}0.8 \% \text { warfarin } \\
0.33 \% \text { apixaban }\end{array}$ & $\begin{array}{l}0.85 \% \text { warfarin } \\
0.26 \% \text { edoxaban } 30 \mathrm{mg}^{*} \\
0.39 \% \text { edoxaban } 60 \mathrm{mg}^{*}\end{array}$ \\
\hline Myocardial infarction & $\begin{array}{l}0.64 \% \text { warfarin } \\
0.82 \% \text { dabigatran } \\
110 \mathrm{mg} \\
0.81 \% \text { dabigatran } \\
150 \mathrm{mg} \\
\end{array}$ & $\begin{array}{l}1.1 \% \text { warfarin } \\
0.9 \% \text { rivaroxaban }\end{array}$ & $\begin{array}{l}0.61 \% \text { warfarin } \\
0.53 \% \text { apixaban }\end{array}$ & $\begin{array}{l}0.75 \% \text { warfarin } \\
0.70 \% \text { edoxaban } 30 \mathrm{mg} \\
0.89 \% \text { edoxaban } 60 \mathrm{mg}\end{array}$ \\
\hline $\begin{array}{l}\text { Incremental cost } \\
\text { per QALY gained } \\
\text { (vs warfarin) })^{57,58}\end{array}$ & $\begin{array}{l}\$ 66,354 \text { - dabigatran } \\
110 \mathrm{mg} \\
\$ 20,797 \text { - dabigatran } \\
150 \mathrm{mg}\end{array}$ & $\$ 55,757$ & $\$ 24,312$ & $\begin{array}{l}\$ 67,320 \text { - edoxaban } \\
30 \mathrm{mg} \\
\$ 46,393 \text { - edoxaban } \\
60 \mathrm{mg}\end{array}$ \\
\hline
\end{tabular}

${ }^{*} P<0.05$.

QALY, quality-adjusted life-year.

with a significant reduction of stroke and major bleeding, including hemorrhagic stroke and overall mortality. The meta-analysis also indicated a trend toward reduced major bleeding. ${ }^{60}$
The anticoagulant effect of the approved NOACs occurs and declines rapidly; therefore, the recommended dosage regimen needs to be closely followed to avoid any thromboembolic complications resulting from 
inadequate anticoagulation. ${ }^{1,12}$ If a dose of dabigatran or apixaban with a twice-daily regimen is missed, the forgotten dose can be taken up to 6 hours after the scheduled ingestion; ${ }^{12}$ if missed for longer than 6 hours, the missed dose should be skipped and the regularly scheduled dose taken on time. If more than one dose was taken within the period of 6 hours, the planned dose at 12 hours should be skipped with resumption of the regular dose at the next scheduled time. For rivaroxaban with once-daily administration, the missed dose can be taken up to 12 hours later, or skipped after 12 hours, with resumption of the next scheduled dose. For double dosing, rivaroxaban can be continued at the regular interval without skipping the next dosage. ${ }^{54}$ If a dose of edoxaban is missed, the dose should be taken as soon as possible on the same day. Dosing should resume the next day according to the normal dosing schedule. The dose should not be doubled to make up for a missed dose. Patient education about nonadherence, risk of stroke or overdose, risk of bleeding, potential side effects and drug-food interactions is especially important in the elderly. ${ }^{61}$

\section{Reversal Agents for NOACs}

Lack of readily available reversal agents for the anticoagulant effect of NOACs was one of the serious concerns that recently has been addressed. ${ }^{62}$ Idarucizumab (Praxbind), a specific antibody against dabigatran, completely reverses the anticoagulant effect of dabigatran within minutes and has been approved by the U.S. Food and Drug Administration (FDA) for this purpose. ${ }^{63}$ Andexanet, a recombinant modified human factor Xa decoy protein, reverses the anticoagulant activity of apixaban and rivaroxaban within minutes after administration and for the duration of infusion, without evidence of clinical toxic effects. ${ }^{64}$ This drug is currently under investigation and is not yet FDAapproved for use as a reversal agent.

\section{Drug-Drug Interactions With NOACs}

All NOACs are substrates of the P-glycoprotein transport system and are thus susceptible to drug interactions with both inhibitors and inducers of this system (Table 3). ${ }^{65-69}$ In addition, rivaroxaban undergoes hepatic transformation primarily via the cytochrome P-450 system (CYP), which includes both the 3A4 and 2J2 families of enzymes. Due to the involvement of CYP3A4, plasma concentrations of rivaroxaban can become elevated or reduced in the presence of strong inhibitors or inducers. ${ }^{66,67}$ Changes in plasma concentrations are most pronounced when rivaroxaban is administered with medications that affect both CYP3A4 and P-glycoprotein, which can result in increased or decreased anticoagulation depending on the interacting agent. ${ }^{65}$ Similar to rivaroxaban, apixaban is a substrate for both CYP3A4 and P-glycoprotein, making it susceptible to numerous drug-drug interactions, particularly with agents that affect both pathways..$^{67,70}$ Edoxaban is also a substrate of cytochrome P-450 3A4 (CYP3A4). ${ }^{71}$ There is an increased risk of bleeding associated with concurrent use of NOACs with other anticoagulants, antiplatelet agents and nonsteroidal antiinflammatory drugs.

\section{Novel Nonpharmacological Strategies to Reduce Thromboembolism}

Most patients with AF at high risk of stroke based on the $\mathrm{CHA}_{2} \mathrm{DS}_{2}$-VASc score should be therapeutically anticoagulated to reduce said risk. However, the risk of bleeding with anticoagulants remains high in the elderly and other patients with unstable gait, a history of intracranial or severe recurrent gastrointestinal bleed, or thrombocytopenia or coagulation defects. This risk could be unacceptably high, highlighting the need for approaches to reduce the risk of stroke without increasing the risk of bleeding. Based on observations that left atrial clots are localized to the LAA more than $90 \%$ of the time, ${ }^{9}$ surgical excision of the LAA or mechanical devices that occlude or exclude the LAA from circulation by ligating its opening into the left atrium have been developed for reduction in thromboembolic risk.

\section{Surgical Excision or Transcutaneous Occlusion/} Isolation of Left Atrial Appendage: In AF patients undergoing open heart surgery for mitral valve or the Maze procedure for AF, surgical ligation, occlusion or amputation of the LAA has been performed without any added morbidity and with reduction in the risk of thromboembolism as compared to those without this procedure. ${ }^{9}$ However, incomplete closure of the LAA has been documented in a large number of patients who continue to be at risk for thromboembolic events. ${ }^{72}$ Stand-alone thoracoscopic left atrial appendectomy in patients with AF and prior thromboembolism who had contraindications to oral anticoagulation demonstrated the feasibility of this approach along with reduction in 
Table 3. Characteristics and Outcomes of Novel Anticoagulant Studies

\begin{tabular}{|c|c|c|c|c|}
\hline NOAC & $\begin{array}{l}\text { CYP3A4 } \\
\text { inhibition }\end{array}$ & $\begin{array}{l}\text { CYP3A4 } \\
\text { induction }\end{array}$ & $\begin{array}{l}\text { RP-glycoprotein } \\
\text { inhibition }\end{array}$ & $\begin{array}{l}\text { P-glycoprotein } \\
\text { induction }\end{array}$ \\
\hline Dabigatran & - & - & $\begin{array}{c}\text { Increased } \\
\text { concentrations }\end{array}$ & $\begin{array}{c}\text { Decreased } \\
\text { concentrations }\end{array}$ \\
\hline Rivaroxaban & $\begin{array}{c}\text { Increased } \\
\text { concentrations }\end{array}$ & $\begin{array}{c}\text { Decreased } \\
\text { concentrations }\end{array}$ & $\begin{array}{c}\text { Increased } \\
\text { concentrations }\end{array}$ & $\begin{array}{c}\text { Decreased } \\
\text { concentrations }\end{array}$ \\
\hline Apixaban & $\begin{array}{c}\text { Increased } \\
\text { concentrations }\end{array}$ & $\begin{array}{c}\text { Decreased } \\
\text { concentrations }\end{array}$ & $\begin{array}{c}\text { Increased } \\
\text { concentrations }\end{array}$ & $\begin{array}{c}\text { Decreased } \\
\text { concentrations }\end{array}$ \\
\hline Edoxaban & - & - & $\begin{array}{c}\text { Increased } \\
\text { concentrations }\end{array}$ & $\begin{array}{c}\text { Decreased } \\
\text { concentrations }\end{array}$ \\
\hline Examples & $\begin{array}{c}\text { Strong } \\
\text { Azole antifungals } \\
\text { Clarithromycin } \\
\text { Conivaptan } \\
\text { Grapefruit } \\
\text { HIV protease } \\
\text { inhibitors } \\
\text { Holkira pak } \\
\text { Idelalisib } \\
\text { Nefazodone } \\
\text { Posaconazole } \\
\text { Technivie } \\
\text { Telithromycin } \\
\text { Viekira Pak } \\
\text { Voriconazole } \\
\\
\text { Moderate } \\
\text { Aprepitant } \\
\text { Ciprofloxacin } \\
\text { Crizotinib } \\
\text { Diltiazem } \\
\text { Dronedarone } \\
\text { Erythromycin } \\
\text { Fluconazole } \\
\text { Imatinib } \\
\text { Netupitant } \\
\text { Verapamil }\end{array}$ & $\begin{array}{c}\text { Carbamazepine } \\
\text { Dexamethasone } \\
\text { Fosamprenavir } \\
\text { Lumacaftor } \\
\text { Nevirapine } \\
\text { Phenobarbital } \\
\text { Phenytoin } \\
\text { Rifabutin } \\
\text { Rifapentine } \\
\text { Rifampin } \\
\text { St. John's wort }\end{array}$ & $\begin{array}{c}\text { Strong } \\
\text { Amiodarone } \\
\text { Azole antifungals } \\
\text { Clarithromycin } \\
\text { Cyclosporine } \\
\text { Dronaderone } \\
\text { Flibanserin } \\
\text { Lapatinib } \\
\text { Nicardipine } \\
\text { Quinidine } \\
\text { Ritonavir } \\
\text { Verapamil } \\
\text { Other notables } \\
\text { (also at least } \\
\text { moderately inhibit } \\
\text { CYP3A4) } \\
\text { Conivaptan } \\
\text { Crizotinib } \\
\text { Diltiazem } \\
\text { Erythromycin } \\
\text { Grapefruit } \\
\text { HIV protease inhibitors } \\
\text { Idelalisib } \\
\text { Imatinib } \\
\text { Nefazodone } \\
\text { Netupitant } \\
\text { Posaconazole } \\
\text { Telithromycin }\end{array}$ & $\begin{array}{c}\text { Strong } \\
\text { Carbamazepine } \\
\text { Phenobarbital } \\
\text { Phenytoin } \\
\text { Rifampin } \\
\text { St. John's wort } \\
\text { Other notables } \\
\frac{\text { (also induce }}{\text { CYP3A4) }} \\
\text { Dexamethasone } \\
\text { Fosamprenavir } \\
\text { Lumacaftor } \\
\text { Nevirapine } \\
\text { Rifabutin } \\
\text { Rifapentine }\end{array}$ \\
\hline
\end{tabular}

HIV, human immunodeficiency virus; NOAC, novel oral anticoagulant.

thromboembolism. ${ }^{73}$ Surgical exclusion of LAA using the AtriClip device (AtriCure Inc., Mason, $\mathrm{OH}$ ) also can be performed successfully in patients undergoing open chest surgery or using a right mini-thoracotomy incision. ${ }^{74}$ Findings from the LAAOS (Left Atrial Appendage Occlusion Study) pilot study demonstrated the safety and feasibility of LAA occlusion during cardiac surgery; and the efficacy of this approach is being tested in a large randomized trial (LAAOS III) in patients undergoing cardiac surgery. ${ }^{75,76}$ A 59\% risk reduction of stroke compared with the expected rate based on $\mathrm{CHAD}_{2} \mathrm{DS}_{2}-\mathrm{VASc}$ score and a $61 \%$ risk reduction of bleeding compared with the expected rate based on HAS-BLED score was demonstrated in observational studies of the Amplatzer ${ }^{\mathrm{TM}}$ Cardiac Plug and secondgeneration Amplatzer Amulet ${ }^{\mathrm{TM}}$ endovascular LAA occluder devices (St. Jude Medical Inc., St. Paul, MN), not yet approved by the FDA. ${ }^{77,78}$ The Amplatzer cardiac plug has received European regulatory approval and is available for clinical use in Europe.

Various percutaneous approaches for LAA occlusion have been developed utilizing a transfemoral transseptal puncture to enable device implant into the LAA or a hybrid transseptal and epicardial approach for LAA closure. ${ }^{9}$ Among these, the Watchman ${ }^{\mathrm{TM}}$ device (Boston Scientific Corp., Marlborough, MA), a selfexpandable nitinol cage deployed in the LAA using a 
transseptal approach, was assessed in two randomized trials (PROTECT AF and PREVAIL) in patients with nonvalvular AF eligible for oral anticoagulation $\left(\mathrm{CHADS}_{2}\right.$ score $\left.\left.>1\right)\right)^{79,80} \mathrm{~A}$ comparable efficacy and safety of the Watchman device to warfarin for the prevention of stroke and systemic embolization was demonstrated in PROTECT AF. ${ }^{79}$ In the follow-up PREVAIL trial, in high-risk patients with nonvalvular AF, noninferiority of LAA occlusion to warfarin anticoagulation was not achieved for the overall efficacy (composite of stroke, systemic embolism and cardiovascular/unexplained death); however, noninferiority was demonstrated for ischemic stroke prevention or systemic embolism $>7$ days postprocedure. ${ }^{80}$ Based on these results, the Watchman device was approved by the FDA for patients with nonvalvular AF for whom long-term anticoagulation is indicated and who are able to tolerate warfarin for at least 6 weeks after device implantation. The use of Watchman in high-risk AF patients ineligible for oral anticoagulation was tested in ASAP (Aspirin Plavix Feasibility Study With Watchman Left Atrial Appendage Closure Technology), a prospective, multicenter, nonrandomized study that demonstrated a lower incidence of stroke or systemic embolism compared to those taking aspirin or clopidogrel. ${ }^{81}$

The Lariat ${ }^{\circledR}$ (SentreHEART Inc., Redwood City, CA), an LAA exclusion device currently being used "offlabel" in the United States for AF patients, consists of a pre-tied suture enclosed in a closed snare that is deployed transcutaneously using a hybrid transfemoral catheter-based endocardial and epicardial approach. ${ }^{82}$ In the U.S. Transcatheter LAA Ligation Consortium's retrospective assessment of 154 patients, the procedural success rate was $86 \%$ with major complication rate of $9.7 \%$, including major bleeds and serious pericardial effusions. ${ }^{83}$ Cases of death; cardiac laceration, perforation or LAA detachment from the heart; bleeding; or cardiac tamponade have been reported in a safety communication by the FDA. ${ }^{84}$ The long-term effectiveness of the Lariat with respect to reducing stroke or its safety relative to other approaches needs to be defined in randomized controlled trials. ${ }^{82}$

In patients with $\mathrm{AF}$ who have a high risk of stroke and contraindication to long-term anticoagulation, percutaneous LAA closure by the Watchman device ${ }^{9}$ or surgical excision at the time of cardiac surgery ${ }^{1}$ are reasonable options to reduce the risk of stroke in lieu of taking long-term anticoagulation. Since a significant proportion of strokes in AF patients may originate from aortic arch plaques, the risk of stroke with LAA occlusion may persist; in select patients, carotid diverters aimed at diverting emboli from intracranial circulation may be helpful but require further investigation. ${ }^{82}$

Atrial Ablation of AF Substrate: Per the current guidelines, AF catheter ablation is useful for symptomatic paroxysmal AF refractory or intolerant to at least one class I or III antiarrhythmic medication when a rhythm-control strategy is desired. ${ }^{1,85} \mathrm{AF}$ catheter ablation to restore sinus rhythm should not be performed with the sole intent of obviating the need for anticoagulation, ${ }^{1}$ especially since the long-term efficacy of radiofrequency catheter ablation in reducing the risk of stroke, particularly in elderly patients with multiple risk factors, is not known.

Radiofrequency catheter ablation of the left atrium has been shown to effectively maintain a majority of patients in sinus rhythm and promote atrial reverse remodeling with a decrease in left atrial volumes and dimensions as well as an improvement in contractility. ${ }^{86,87}$ In a study of AF patients mostly younger than 65 years old, of whom $56 \%$ had one or more risk factor for stroke, successful ablation of the left atrium was associated with discontinuation of anticoagulation in patients with or without risk factors for stroke (except for those older than 65 years old or with a history of stroke). ${ }^{88} \mathrm{~A}$ thromboembolic event rate of $1.1 \%$ within 2 weeks of ablation emphasized the need for anticoagulation for at least 3 months after a procedure, which would facilitate atrial remodeling with a return to sinus rhythm, thereby potentially reducing the risk of thromboembolism. A meta-analysis of eight randomized controlled trials comprising 844 patients showed that radiofrequency catheter ablation decreased atrial tachyarrhythmia recurrence by $71 \%(\mathrm{P}<0.00001)$. Fewer complications and adverse events were reported in the ablation group compared to the control group. ${ }^{89}$ Despite these preliminary results, anticoagulation with warfarin or NOACs should be continued in patients at high risk for thromboembolism (i.e. $\mathrm{CHA}_{2} \mathrm{DS}_{2}$-VASc score $\geq 2$ ).

Surgical ablation also aims to eliminate AF by the use of atrial incisions that prevent propagation of arrhythmia 
while preserving the sinus node and atrial contractility. The Cox Maze procedure ablates the atrial substrate for $\mathrm{AF}$ and removes the LAA to reduce risk of stroke by maintaining sinus rhythm and removing the major site for thrombus formation within the heart. ${ }^{90,91}$ Despite promising findings of surgical follow-up studies, prospective, randomized, multicenter trials are needed to obtain definitive evidence for the most effective treatment approach, energy source for ablation, specific areas of ablation and the true success rate in reducing risk of stroke and $\mathrm{AF}$ recurrence. ${ }^{1}$

\section{Summary}

With the aging of the U.S. population and a projected increase in the prevalence of atrial fibrillation in Americans from about 2.3 million in 2006 to more than 15 million by the year 2050, AF is a major public health problem. ${ }^{92-94}$ Advances in our understanding of the aging-associated changes that form the substrate of AF and thromboembolism in the elderly remain inadequate to fully promote the design of safe and effective strategies to prevent $\mathrm{AF}$ and reduce the associated risk of stroke. Many recognized markers imply a risk of thromboembolism in AF patients, yet the specific mechanisms that initiate and maintain a thrombotic state with AF remains to be fully understood. Regardless of treatment approach (either rate or rhythm control), anticoagulation is of paramount importance in decreasing the risk of thromboembolism in high-risk patients. Both warfarin and newer oral anticoagulants are effective in reducing the risk of thromboembolism in patients with nonvalvular AF but continue to carry risks of bleeding that limit their use in select elderly patients, particularly those with renal impairment. Further studies comparing newer anticoagulation in select patient populations are needed to define specific clinical situations in which one anticoagulant offers a superior benefit-to-risk profile relative to other available treatments.

The management of elderly patients predisposed to thromboembolism mandates addressing the difficult problem of balancing the risk of bleeding with longterm anticoagulation against its proven benefit in reducing stroke risk. Nonpharmacological strategies are limited, not applicable to all patients and require further investigation to prove their equivalence or superiority to anticoagulants in reducing the risk of thromboembolism or other complications in the elderly. Age alone should not be the limiting factor for anticoagulation, which should be considered in all patients unless clearly contraindicated. ${ }^{12}$ Further research is needed to identify initiating factors and critical mediators of thromboembolism and to delineate pathways altered by aging that potentiate the risk for $\mathrm{AF}$ and thromboembolism. ${ }^{11,95}$ With better patient risk-stratification and the design of more appropriate therapeutic strategies, AF-associated thromboembolic risk could be further reduced in elderly patients.

\section{Patient-Friendly Recap}

- Atrial fibrillation (AF) is an abnormal heart rhythm that greatly increases an individual's risk for suffering a stroke.

- To prevent this, many patients with AF take anticoagulant medication such as warfarin.

- The authors report the current state of evidence regarding ways to prevent stroke in elderly patients with $\mathrm{AF}$, who often have complex conditions for which use of anticoagulants may raise the risk of bleeding.

- They concluded anticoagulation is still the most proven treatment for AF in patients at high risk of stroke, but elderly patients should be more closely monitored to avoid potentially dangerous bleeding incidents.

\section{Conflicts of interest}

None.

\section{Funding Sources}

Arshad Jahangir is supported by funding from the National Institutes of Health and Aurora Health Care. The NIH had no role in study design, data collection/ analysis, decision to publish or preparation of the manuscript. The content is solely the responsibility of the authors and does not necessarily represent the official views of the NIH.

\section{References}

1. January CT, Wann LS, Alpert JS, et al. 2014 AHA/ACC/ HRS guideline for the management of patients with atrial fibrillation: executive summary: a report of the American College of Cardiology/American Heart Association Task Force on Practice Guidelines and the Heart Rhythm Society. Circulation. 2014;130:2071-104. CrossRef 
2. Mozaffarian D, Benjamin EJ, Go AS, et al. Heart disease and stroke statistics - 2016 update: a report from the American Heart Association. Circulation. 2016;133:e38-360.

3. Go AS, Hylek EM, Phillips KA, et al. Prevalence of diagnosed atrial fibrillation in adults: national implications for rhythm management and stroke prevention: the AnTicoagulation and Risk Factors in Atrial Fibrillation (ATRIA) study. JAMA. 2001;285:2370-5. CrossRef

4. GBD 2013 Mortality and Causes of Death Collaborators. Global, regional, and national age-sex specific all-cause and cause-specific mortality for 240 causes of death, 1990-2013: a systematic analysis for the Global Burden of Disease Study 2013. Lancet. 2015;385:117-71. CrossRef

5. Olesen JB, Lip GY, Hansen PR, et al. Bleeding risk in 'real world' patients with atrial fibrillation: comparison of two established bleeding prediction schemes in a nationwide cohort. J Thromb Haemost. 2011;9:1460-7. CrossRef

6. Turagam MK, Mirza M, Werner $\mathrm{PH}$, et al. Circulating biomarkers predictive of postoperative atrial fibrillation. Cardiol Rev. 2016;24:76-87. CrossRef

7. Hijazi Z, Lindbäck J, Alexander JH, et al. The ABC (age, biomarkers, clinical history) stroke risk score: a biomarkerbased risk score for predicting stroke in atrial fibrillation. Eur Heart J. 2016;37:1582-90. CrossRef

8. Avgil Tsadok M, Jackevicius CA, Rahme E, Humphries KH, Behlouli H, Pilote L. Sex differences in stroke risk among older patients with recently diagnosed atrial fibrillation. JAMA. 2012;307:1952-8. CrossRef

9. Meier B, Blaauw Y, Khattab AA, et al. EHRA/EAPCI expert consensus statement on catheter-based left atrial appendage occlusion. Europace. 2014;16:1397-416. CrossRef

10. Singer DE, Chang Y, Fang MC, et al. The net clinical benefit of warfarin anticoagulation in atrial fibrillation. Ann Intern Med. 2009;151:297-305. CrossRef

11. Mirza M, Strunets A, Shen WK, Jahangir A. Mechanisms of arrhythmias and conduction disorders in older adults. Clin Geriatr Med. 2012;28:555-73. CrossRef

12. Strunets A, Mirza M, Sra J, Jahangir A. Novel anticoagulants for stroke prevention in atrial fibrillation: safety issues in the elderly. Expert Rev Clin Pharmacol. 2013;6:677-89. CrossRef

13. Turagam MK, Downey FX, Kress DC, Sra J, Tajik AJ, Jahangir A. Pharmacological strategies for prevention of postoperative atrial fibrillation. Expert Rev Clin Pharmacol. 2015;8: 233-250. CrossRef

14. Bogousslavsky J, Van Melle G, Regli F, Kappenberger L. Pathogenesis of anterior circulation stroke in patients with nonvalvular atrial fibrillation: the Lausanne Stroke Registry. Neurology. 1990;40:1046-50. CrossRef

15. Donal E, Lip GY, Galderisi M, et al. EACVI/EHRA expert consensus document on the role of multi-modality imaging for the evaluation of patients with atrial fibrillation. Eur Heart $J$ Cardiovasc Imaging. 2016;17:355-383. CrossRef

16. Meier B, Blaauw Y, Khattab AA, et al. EHRA/EAPCI expert consensus statement on catheter-based left atrial appendage occlusion. EuroIntervention. 2015;10:1109-25. CrossRef

17. Gallagher AM, van Staa TP, Murray-Thomas T, et al. Population-based cohort study of warfarin-treated patients with atrial fibrillation: incidence of cardiovascular and bleeding outcomes. BMJ Open. 2014;4(1):e003839. CrossRef

18. Heidbuchel $\mathrm{H}$, Verhamme $\mathrm{P}$, Alings $\mathrm{M}$, et al. EHRA practical guide on the use of new oral anticoagulants in patients with non-valvular atrial fibrillation: executive summary. Eur Heart $J$. 2013;34:2094-106. CrossRef
19. Johnsen SP, Svendsen ML, Hansen ML, Brandes A, Mehnert F, Husted SE. Preadmission oral anticoagulant treatment and clinical outcome among patients hospitalized with acute stroke and atrial fibrillation: a nationwide study. Stroke. 2014;45: 168-75. CrossRef

20. Benavente O, Hart R, Koudstaal P, Laupacis A, McBride R. Antiplatelet therapy for preventing stroke in patients with nonvalvular atrial fibrillation and no previous history of stroke or transient ischemic attacks. Cochrane Database Syst Rev. 2000;(2):CD001925. CrossRef

21. Lip GY, Windecker S, Huber $\mathrm{K}$, et al. Management of antithrombotic therapy in atrial fibrillation patients presenting with acute coronary syndrome and/or undergoing percutaneous coronary or valve interventions: a joint consensus document of the European Society of Cardiology Working Group on Thrombosis, European Heart Rhythm Association (EHRA), European Association of Percutaneous Cardiovascular Interventions (EAPCI) and European Association of Acute Cardiac Care (ACCA) endorsed by the Heart Rhythm Society (HRS) and Asia-Pacific Heart Rhythm Society (APHRS). Eur Heart J. 2014;35:3155-3179. CrossRef

22. Tofler GH, Massaro J, Levy D, et al. Relation of the prothrombotic state to increasing age (from the Framingham Offspring Study). Am J Cardiol. 2005;96:1280-3. CrossRef

23. Yamashita T. Molecular basis of thromboembolism in association with atrial fibrillation. Circ J. 2007;71 Suppl A:A40-4. CrossRef

24. January CT, Wann LS, Alpert JS, et al. 2014 AHA/ACC/HRS guideline for the management of patients with atrial fibrillation: a report of the American College of Cardiology/American Heart Association Task Force on Practice Guidelines and the Heart Rhythm Society. Circulation. 2014;130:e199-267. CrossRef

25. Friberg L, Rosenqvist M, Lip GY. Net clinical benefit of warfarin in patients with atrial fibrillation: a report from the swedish atrial fibrillation cohort study. Circulation. 2012;125:2298-307. CrossRef

26. Hart RG, Pearce LA, Aguilar MI. Meta-analysis: antithrombotic therapy to prevent stroke in patients who have nonvalvular atrial fibrillation. Ann Intern Med. 2007;146:857-67. CrossRef

27. Banerjee A, Lane DA, Torp-Pedersen C, Lip GY. Net clinical benefit of new oral anticoagulants (dabigatran, rivaroxaban, apixaban) versus no treatment in a 'real world' atrial fibrillation population: a modelling analysis based on a nationwide cohort study. Thromb Haemost. 2012;107:584-9. CrossRef

28. Sandhu RK, Ezekowitz J, Andersson U, et al. The 'obesity paradox' in atrial fibrillation: observations from the ARISTOTLE (Apixaban for Reduction in Stroke and Other Thromboembolic Events in Atrial Fibrillation) trial. Eur Heart J. 2016 Apr 12 [Epub ahead of print]. CrossRef

29. Hylek EM, Go AS, Chang Y, et al. Effect of intensity of oral anticoagulation on stroke severity and mortality in atrial fibrillation. N Engl J Med. 2003;349:1019-26. CrossRef

30. Lip GY, Lim HS. Atrial fibrillation and stroke prevention. Lancet Neurol. 2007;6:981-93. CrossRef

31. Yamamoto K, Takeshita K, Kojima T, Takamatsu J, Saito $\mathrm{H}$. Aging and plasminogen activator inhibitor-1 (PAI-1) regulation: implication in the pathogenesis of thrombotic disorders in the elderly. Cardiovasc Res. 2005;66:276-85. CrossRef

32. Kucher N, Connolly S, Beckman JA, et al. International normalized ratio increase before warfarin-associated hemorrhage: brief and subtle. Arch Intern Med. 2004;164:2176-9. CrossRef 
33. Heidbuchel $H$, Verhamme $P$, Alings $M$, et al. Updated European Heart Rhythm Association Practical Guide on the use of non-vitamin $\mathrm{K}$ antagonist anticoagulants in patients with non-valvular atrial fibrillation. Europace. 2015;17: 1467-507. CrossRef

34. Dayal S, Wilson KM, Motto DG, Miller FJ Jr, Chauhan AK, Lentz SR. Hydrogen peroxide promotes aging-related platelet hyperactivation and thrombosis. Circulation. 2013;127: 1308-16. CrossRef

35. Agarwal S, Hachamovitch R, Menon V. Current trialassociated outcomes with warfarin in prevention of stroke in patients with nonvalvular atrial fibrillation: a meta-analysis. Arch Intern Med. 2012;172:623-31. CrossRef

36. Ozcan C, Jahangir A, Friedman PA, et al. Long-term survival after ablation of the atrioventricular node and implantation of a permanent pacemaker in patients with atrial fibrillation. N Engl J Med. 2001;344:1043-51. CrossRef

37. Sherman DG, Kim SG, Boop BS, et al. Occurrence and characteristics of stroke events in the Atrial Fibrillation Followup Investigation of Sinus Rhythm Management (AFFIRM) study. Arch Intern Med. 2005;165:1185-91. CrossRef

38. Van Gelder IC, Hagens VE, Bosker HA, et al. A comparison of rate control and rhythm control in patients with recurrent persistent atrial fibrillation. $N$ Engl J Med. 2002;347:1834-40. CrossRef

39. Roy D, Talajic M, Nattel S, et al. Rhythm control versus rate control for atrial fibrillation and heart failure. $N$ Engl $J$ Med. 2008;358:2667-77. CrossRef

40. Wyse DG, Waldo AL, DiMarco JP, et al. A comparison of rate control and rhythm control in patients with atrial fibrillation. N Engl J Med. 2002;347:1825-33. CrossRef

41. Israel CW, Grönefeld G, Ehrlich JR, Li YG, Hohnloser SH. Long-term risk of recurrent atrial fibrillation as documented by an implantable monitoring device: implications for optimal patient care. J Am Coll Cardiol. 2004;43:47-52. CrossRef

42. Boriani G, Glotzer TV, Santini M, et al. Device-detected atrial fibrillation and risk for stroke: an analysis of $>10,000$ patients from the SOS AF project (Stroke preventiOn Strategies based on Atrial Fibrillation Information from implanted devices). Eur Heart J. 2014;35:508-16. CrossRef

43. Brachmann J, Morillo CA, Sanna T, et al. Uncovering atrial fibrillation beyond short-term monitoring in cryptogenic stroke patients: three-year results from the Cryptogenic Stroke and Underlying Atrial Fibrillation trial. Circ Arrhythm Electrophysiol. 2016;9(1):e003333. CrossRef

44. Lane DA, Lip GY. Use of the CHA(2)DS(2)-VASc and HASBLED scores to aid decision making for thromboprophylaxis in nonvalvular atrial fibrillation. Circulation. 2012;126:860-5. CrossRef

45. Atrial Fibrillation Investigators. Risk factors for stroke and efficacy of antithrombotic therapy in atrial fibrillation. Analysis of pooled data from five randomized controlled trials. Arch Intern Med. 1994;154:1449-57.

46. Gage BF, Waterman AD, Shannon W, Boechler M, Rich MW, Radford MJ. Validation of clinical classification schemes for predicting stroke: results from the National Registry of Atrial Fibrillation. JAMA. 2001;285:2864-70. CrossRef

47. Joundi RA, Cipriano LE, Sposato LA, Saposnik G; Stroke Outcomes Research Working Group. Ischemic stroke risk in patients with atrial fibrillation and CHA2DS2-VASc score of 1: systematic review and meta-analysis. Stroke. 2016;47: 1364-7. $\underline{\text { CrossRef }}$
48. Sartori MT, Prandoni P. How to effectively manage the event of bleeding complications when using anticoagulants. Expert Rev Hematol. 2016;9:37-50. CrossRef

49. Thon JM, Gurol ME. Intracranial hemorrhage risk in the era of antithrombotic therapies for ischemic stroke. Curr Treat Options Cardiovasc Med. 2016;18(5):29. CrossRef

50. O'Brien EC, Holmes DN, Ansell JE, et al. Physician practices regarding contraindications to oral anticoagulation in atrial fibrillation: findings from the Outcomes Registry for Better Informed Treatment of Atrial Fibrillation (ORBIT-AF) registry. Am Heart J. 2014;167:601-9.e1. CrossRef

51. Pautas E, Moreau C, Gouin-Thibault I, et al. Genetic factors (VKORC1, CYP2C9, EPHX1, and CYP4F2) are predictor variables for warfarin response in very elderly, frail inpatients. Clin Pharmacol Ther. 2010;22:57-64. CrossRef

52. Aronis KN, Hylek EM. Who, when, and how to reverse non-vitamin $\mathrm{K}$ oral anticoagulants. $J$ Thromb Thrombolysis. 2016;41:253-72. CrossRef

53. Connolly SJ, Ezekowitz MD, Yusuf S, et al. Dabigatran versus warfarin in patients with atrial fibrillation. $N$ Engl $\mathrm{J} \mathrm{Med}$. 2009;361:1139-51. CrossRef

54. Patel MR, Mahaffey KW, Garg J, et al. Rivaroxaban versus warfarin in nonvalvular atrial fibrillation. $N$ Engl $\mathrm{J} \mathrm{Med.}$ 2011;365:883-91. CrossRef

55. Granger CB, Alexander JH, McMurray JJ, et al. Apixaban versus warfarin in patients with atrial fibrillation. $N$ Engl $J$ Med. 2011;365:981-92. CrossRef

56. Giugliano RP, Ruff CT, Braunwald E, et al. Edoxaban versus warfarin in patients with atrial fibrillation. $N$ Engl $\mathrm{J} \mathrm{Med.}$ 2013;369:2093-104. CrossRef

57. Coyle D, Coyle K, Cameron C, et al. Cost-effectiveness of new oral anticoagulants compared with warfarin in preventing stroke and other cardiovascular events in patients with atrial fibrillation. Value Health. 2013;16:498-506. CrossRef

58. Magnuson EA, Vilain K, Wang K, et al. Cost-effectiveness of edoxaban vs warfarin in patients with atrial fibrillation: results from the ENGAGE AF-TIMI 48 economic study. (abstr.) Circulation. 2014;130(Suppl 2):A16534.

59. Ruff CT, Giugliano RP, Braunwald E, et al. Comparison of the efficacy and safety of new oral anticoagulants with warfarin in patients with atrial fibrillation: a meta-analysis of randomised trials. Lancet. 2014;383:955-62. CrossRef

60. Dentali F, Riva N, Crowther M, Turpie AG, Lip GY, Ageno W. Efficacy and safety of the novel oral anticoagulants in atrial fibrillation: a systematic review and meta-analysis of the literature. Circulation. 2012;126:2381-91. CrossRef

61. Daiichi Sankyo Co. Edoxaban medication guide [package insert, 2015]. http://dsi.com/prescribing-information-portlet/ getPIContent?productName $=$ Savaysa $\% 20$ Med\&inline $=$ true . Accessed Oct. 10, 2016.

62. Liotta EM, Levasseur-Franklin KE, Naidech AM. Reversal of the novel oral anticoagulants dabigatran, rivoraxaban, and apixaban. Curr Opin Crit Care. 2015;21:127-33. CrossRef

63. Pollack CV Jr, Reilly PA, Eikelboom J, et al. Idarucizumab for dabigatran reversal. $N$ Engl J Med. 2015;373:511-20. CrossRef

64. Siegal DM, Curnutte JT, Connolly SJ, et al. Andexanet alfa for the reversal of factor Xa inhibitor activity. $N$ Engl J Med. 2015;373:2413-24. CrossRef

65. Walenga JM, Adiguzel C. Drug and dietary interactions of the new and emerging oral anticoagulants. Int J Clin Pract. 2010;64:956-67. CrossRef 
66. Abrams PJ, Emerson CR. Rivaroxaban: a novel, oral, direct factor Xa inhibitor. Pharmacotherapy. 2009;29:167-81. CrossRef

67. Eriksson BI, Quinlan DJ, Weitz JI. Comparative pharmacodynamics and pharmacokinetics of oral direct thrombin and factor $\mathrm{Xa}$ inhibitors in development. Clin Pharmacokinet. 2009;48:1-22. CrossRef

68. Sanford M, Plosker GL. Dabigatran etexilate. Drugs. 2008;68:1699-709. CrossRef

69. Stangier J. Clinical pharmacokinetics and pharmacodynamics of the oral direct thrombin inhibitor dabigatran etexilate. Clin Pharmacokinet. 2008;47:285-95. CrossRef

70. Shantsila E, Lip GY. Apixaban, an oral, direct inhibitor of activated factor Xa. Curr Opin Investig Drugs. 2008;9:1020-33.

71. Mendell J, Zahir H, Matsushima N, et al. Drug-drug interaction studies of cardiovascular drugs involving P-glycoprotein, an efflux transporter, on the pharmacokinetics of edoxaban, an oral factor Xa inhibitor. Am J Cardiovasc Drugs. 2013;13: 331-42. CrossRef

72. Kanderian AS, Gillinov AM, Pettersson GB, Blackstone E, Klein AL. Success of surgical left atrial appendage closure: assessment by transesophageal echocardiography. J Am Coll Cardiol. 2008;52:924-9. CrossRef

73. Ohtsuka T, Ninomiya M, Nonaka T, Hisagi M, Ota T, Mizutani T. Thoracoscopic stand-alone left atrial appendectomy for thromboembolism prevention in nonvalvular atrial fibrillation. J Am Coll Cardiol. 2013;62:103-7. CrossRef

74. Ailawadi G, Gerdisch MW, Harvey RL, et al. Exclusion of the left atrial appendage with a novel device: early results of a multicenter trial. J Thorac Cardiovasc Surg. 2011;142:1002-9. CrossRef

75. Whitlock RP, Vincent J, Blackall MH, et al. Left Atrial Appendage Occlusion Study II (LAAOS II). Can J Cardiol. 2013;29:1443-7. CrossRef

76. Whitlock R, Healey J, Vincent J, et al. Rationale and design of The Left Atrial Appendage Occlusion Study (LAAOS) III. Ann Cardiothorac Surg. 2014;3:45-54. CrossRef

77. Holmes DR Jr, Doshi SK, Kar S, et al. Left atrial appendage closure as an alternative to warfarin for stroke prevention in atrial fibrillation: a patient-level meta-analysis. J Am Coll Cardiol. 2015;65:2614-23. CrossRef

78. Tzikas A, Shakir S, Gafoor S, et al. Left atrial appendage occlusion for stroke prevention in atrial fibrillation: multicentre experience with the AMPLATZER cardiac plug. EuroIntervention. 2016;11:1170-9. CrossRef

79. Reddy VY, Holmes D, Doshi SK, Neuzil P, Kar S. Safety of percutaneous left atrial appendage closure: results from the Watchman Left Atrial Appendage System for Embolic Protection in Patients with AF (PROTECT AF) clinical trial and the Continued Access Registry. Circulation. 2011;123: 417-24. CrossRef

80. Holmes DR Jr, Kar S, Price MJ, et al. Prospective randomized evaluation of the Watchman left atrial appendage closure device in patients with atrial fibrillation versus long-term warfarin therapy: the PREVAIL trial. J Am Coll Cardiol. 2014;64:1-12. CrossRef
81. Reddy VY, Möbius-Winkler S, Miller MA, et al. Left atrial appendage closure with the Watchman device in patients with a contraindication for oral anticoagulation: the ASAP study (ASA Plavix Feasibility Study With Watchman Left Atrial Appendage Closure Technology). J Am Coll Cardiol. 2013;61:2551-6. $\underline{\text { CrossRef }}$

82. Masoudi FA, Calkins H, Kavinsky CJ, et al. 2015 ACC/HRS/ SCAI left atrial appendage occlusion device societal overview. J Am Coll Cardiol. 2015;66:1497-513. CrossRef

83. Price MJ, Gibson DN, Yakubov SJ, et al. Early safety and efficacy of percutaneous left atrial appendage suture ligation: results from the U.S. transcatheter LAA ligation consortium. J Am Coll Cardiol. 2014;64:565-72. CrossRef

84. U.S. Food and Drug Administration. Use of LARIAT suture delivery device for left atrial appendage closure: FDA safety communication (issued July 13, 2015). http://www.fda.gov/ medicaldevices/safety/alertsandnotices/ucm454501.htm. Accessed Oct. 10, 2016.

85. Haegeli LM, Calkins H. Catheter ablation of atrial fibrillation: an update. Eur Heart J. 2014;35:2454-9. CrossRef

86. Tops LF, Bax JJ, Zeppenfeld K, Jongbloed MR, van der Wall EE, Schalij MJ. Effect of radiofrequency catheter ablation for atrial fibrillation on left atrial cavity size. Am J Cardiol. 2006;97:1220-2. CrossRef

87. Tops LF, Delgado V, Bertini M, et al. Left atrial strain predicts reverse remodeling after catheter ablation for atrial fibrillation. J Am Coll Cardiol. 2011;57:324-31. CrossRef

88. Oral H, Chugh A, Ozaydin M, et al. Risk of thromboembolic events after percutaneous left atrial radiofrequency ablation of atrial fibrillation. Circulation. 2006;114:759-65. CrossRef

89. Bonanno C, Paccanaro M, La Vecchia L, Ometto R, Fontanelli A. Efficacy and safety of catheter ablation versus antiarrhythmic drugs for atrial fibrillation: a meta-analysis of randomized trials. J Cardiovasc Med (Hagerstown). 2010;11:408-18. CrossRef

90. Cox JL. A brief overview of surgery for atrial fibrillation. Ann Cardiothorac Surg. 2014;3:80-8. CrossRef

91. Gillinov AM, Gelijns AC, Parides MK, et al. Surgical ablation of atrial fibrillation during mitral-valve surgery. $N$ Engl J Med. 2015;372:1399-409. CrossRef

92. Jahangir A, Sagar S, Terzic A. Aging and cardioprotection. J Appl Physiol (1985). 2007;103:2120-8. CrossRef

93. Miyasaka Y, Barnes ME, Gersh BJ, et al. Time trends of ischemic stroke incidence and mortality in patients diagnosed with first atrial fibrillation in 1980 to 2000: report of a community-based study. Stroke. 2005;36:2362-6. CrossRef

94. Miyasaka Y, Barnes ME, Gersh BJ, et al. Secular trends in incidence of atrial fibrillation in Olmsted County, Minnesota, 1980 to 2000, and implications on the projections for future prevalence. Circulation. 2006;114:119-25. CrossRef

95. Jahangir A, Lee V, Friedman PA, et al. Long-term progression and outcomes with aging in patients with lone atrial fibrillation: a 30-year follow-up study. Circulation. 2007;115:3050-6. CrossRef

(C) 2016 Aurora Health Care, Inc. 